\title{
The Influence of Chinese Teachers' Gender and Educational Background on Teachers' Job Satisfaction -- Analysis Based on 2015 PISA Data
}

\author{
Yan Du \\ Department of Education in East China Normal University, Shanghai, 200062, China \\ dualisa@163.com
}

Keywords: Chinese teachers, gender, educational background, job satisfaction, PISA

\begin{abstract}
Job satisfaction affects teachers' motivation, investment and performance to a great extent, and then affects the development of students and the improvement of school education quality. At present, there are a lot of researches on teachers' job satisfaction. There are many factors affecting teachers' job satisfaction, such as teachers' gender, educational background, and the support of principals. Based on the teacher survey data of the Programme for International Student Assessment (PISA) in 2015, this study analyzed whether gender and educational background of Chinese teachers have differences in the job satisfaction of teachers. It is found that gender and educational background have no significant influence on teachers' job satisfaction.
\end{abstract}

\section{Introduction}

Job satisfaction affects teachers' motivation, investment and performance to a great extent, and then affects the development of students and the improvement of school education quality. At present, there are a lot of researches on teachers' job satisfaction. There are many factors affecting teachers' job satisfaction, such as teachers' gender, educational background, and the support of principals. Based on the teacher survey data of the Programme for International Student Assessment (PISA) of four Chinese provinces (cities) and some OECD member countries in 2015, this study analyzes whether there are differences in teacher job satisfaction between the gender and educational background of Chinese teachers. The analysis of this study mainly involves the following questions in the 2015 PISA questionnaire: teacher gender (teacher version questionnaire P3, TC001Q01); teacher's degree (teacher's version of questionnaire P11, TC012Q01); teachers' job satisfaction (teacher's questionnaire P29, TC026Q10 NA01 -- 04).

\section{Descriptive statistics of datum}

The data used in this paper are from the Programme for International Student Assessment (PISA) conducted by the organization for economic cooperation and development (OECD) in 72 countries and regions in 2015.In 2015, PISA tested and surveyed 268 principals, 6,423 teachers and 9,841 students from 268 middle schools in Beijing, Shanghai, Guangdong and Jiangsu provinces. PISA is 
sampled in two stages, first by stratified random sampling of schools, and then by random selection of a specific proportion and number of students and teachers in each school.

This study mainly analyzes the questionnaire data of teachers in China. The geographical distribution of the schools of teachers participating in the PISA survey is shown in table 1.

Table 1 Urban and rural distribution of teacher samples in four provinces and cities of China in PISA 2015

\begin{tabular}{|c|c|c|c|c|c|}
\hline & & $\begin{array}{c}\text { Number of } \\
\text { sample schools }\end{array}$ & $\begin{array}{c}\text { Number of } \\
\text { sample teachers }\end{array}$ & $\begin{array}{c}\text { Weighted sample } \\
\text { number of teachers }\end{array}$ & $\begin{array}{c}\text { Proportion of weighted samples } \\
\text { in effective samples (\%) }\end{array}$ \\
\hline Cities & & 97 & 2303 & 61977 & 35.03 \\
\hline & Big cities & 60 & 1414 & 39977 & 22.60 \\
\hline & $\begin{array}{c}\text { Small and } \\
\text { medium cities }\end{array}$ & 37 & 889 & 22000 & 61.64 \\
\hline $\begin{array}{c}\text { Villages and } \\
\text { towns }\end{array}$ & & 165 & 3990 & 109040 & 8.78 \\
\hline & Villages & 31 & 703 & 15528 & 52.86 \\
\hline Others & Town & 134 & 3287 & 93512 & 3.33 \\
\hline Total & & 6 & 130 & 5891 & 100.00 \\
\hline
\end{tabular}

The data in table 1 shows that the 6,423 randomly selected teachers represent nearly 177,000 full-time teachers in all kinds of middle schools in four provinces and cities in China. The weighted sample number of teachers was 176,908, accounting for $19.5 \%$ of the total number of full-time middle school teachers $(907,221)$ in the four provinces (cities) of China. Among them, urban teachers accounted for $35.03 \%$ of the total number of teachers, and teachers in towns and other areas accounted for $64.97 \%$.

The description statistics of teachers' gender are shown in the following table:

Table 2 Teacher gender distribution table

\begin{tabular}{|c|c|c|c|c|c|}
\hline \multicolumn{7}{|c|}{ Are you male or female? } \\
\hline \multirow{3}{*}{ Effective } & Frequency & Percentage & Effective percentage & Cumulative Percent \\
\cline { 2 - 6 } & Women & 3615 & 56.3 & 57.6 & 57.6 \\
\hline & Men & 2663 & 41.5 & 42.4 & 100.0 \\
\hline \multirow{3}{*}{ Missing } & Total & 6278 & 97.7 & 100.0 & \\
\cline { 2 - 6 } & No Response & 17 & .3 & & \\
\cline { 2 - 6 } & System & 128 & 2.0 & & \\
\cline { 2 - 6 } & Total & 145 & 2.3 & & \\
\hline \multicolumn{2}{|c|}{ Total } & 6423 & 100.0 & & \\
\hline
\end{tabular}

The descriptive statistics of teachers' qualifications are shown in the following table: 
Table 3 The distribution table of the highest educational qualifications of teachers

\begin{tabular}{|c|c|c|c|c|c|}
\hline \multicolumn{6}{|c|}{ What is the highest degree you have completed in formal education? } \\
\hline & & Frequency & Percentage & Effective percentage & Cumulative Percent \\
\hline \multirow{6}{*}{ Effective } & Below higher education & 36 & .6 & .6 & .6 \\
\hline & Junior college & 590 & 9.2 & 9.4 & 10.0 \\
\hline & Bachelor & 5176 & 80.6 & 82.3 & 92.3 \\
\hline & Master & 470 & 7.3 & 7.5 & 99.8 \\
\hline & Phd & 14 & .2 & .2 & 100.0 \\
\hline & Total & 6286 & 97.9 & 100.0 & \\
\hline \multirow{3}{*}{ Missing } & No Response & 9 & .1 & & \\
\hline & System & 128 & 2.0 & & \\
\hline & Total & 137 & 2.1 & & \\
\hline \multicolumn{2}{|r|}{ Total } & 6423 & 100.0 & & \\
\hline
\end{tabular}

The following table can be obtained by merging teachers with junior college degrees below the higher education level and those with master's and doctor's degrees.

Table 4 Combined table of teachers' highest academic qualifications

\begin{tabular}{|c|c|c|c|c|c|}
\hline \multicolumn{6}{|c|}{ What is the highest degree you have completed in formal education? } \\
\hline \multirow{4}{*}{ Effective } & Frequency & Percentage & Effective percentage & Cumulative Percent \\
\cline { 2 - 6 } & Junior college and below & 626 & 9.7 & 10.0 & 10.0 \\
\cline { 2 - 6 } & Bachelor & 5176 & 80.6 & 82.3 & 92.3 \\
\cline { 2 - 6 } & Master and phd & 484 & 7.5 & 7.7 & 100.0 \\
\hline \multirow{3}{*}{ Missing } & Total & 6286 & 97.9 & 100.0 & \\
\cline { 2 - 6 } & No Response & 9 & .1 & & \\
\cline { 2 - 6 } & system & 128 & 2.0 & & \\
\cline { 2 - 6 } & Total & 137 & 2.1 & & \\
\hline \multicolumn{2}{|c|}{ Total } & 6423 & 100.0 & & \\
\hline
\end{tabular}

In 2015, PISA added teacher questionnaires to the new round of tests, and teacher job satisfaction is an important part of the PISA 2015 survey.TC026 is composed of 8 Likert questions with 4 points. Questions 1-7 listed some teachers' statements about their profession, work unit or job performance. Question 8 asked teachers about their job satisfaction as a whole, asking them to report the degree of "agreement" or "disagreement. The overall Alpha reliability coefficient of the scale is 0.849 , indicating that the scale has a high internal consistency reliability. This study only analyzed the data of question 8. Chinese teachers' answers to question 8 are as follows:

Table 5 Distribution table of teachers' job satisfaction

\begin{tabular}{|c|c|c|c|c|c|}
\hline \multicolumn{7}{|c|}{ All in all, I am satisfied with my work } \\
\hline \multirow{4}{*}{ Effective } & Frequency & Percentage & Effective percentage & Cumulative Percent \\
\hline & Strongly disagree & 79 & 1.2 & 1.3 & 1.3 \\
\cline { 2 - 6 } & Disagree & 591 & 9.2 & 9.5 & 10.7 \\
\cline { 2 - 6 } & Agree & 3961 & 61.7 & 63.4 & 74.1 \\
\cline { 2 - 6 } & Totally agree & 1616 & 25.2 & 25.9 & 100.0 \\
\cline { 2 - 6 } Missing & Total & 6247 & 97.3 & 100.0 & \\
\hline & No Response & 48 & .7 & & \\
\cline { 2 - 6 } & System & 128 & 2.0 & & \\
\cline { 2 - 6 } & Total & 176 & 2.7 & & \\
\hline \multicolumn{7}{|c|}{ Total } & 6423 & 100.0 & & \\
\hline
\end{tabular}




\section{Hypothesis testing}

\subsection{The influence of teacher gender on teacher job satisfaction}

Null hypothesis H0: There was no difference between male and female teachers in their job satisfaction.

Alternative hypothesis H1: There are differences between male and female teachers in their job satisfaction.

Significance level $\alpha=0.05$

Test method: independent sample T test.

Table 6 Statistical table of teacher gender description

\begin{tabular}{|c|c|c|c|c|c|}
\hline \multicolumn{7}{|c|}{ Statistics Group } \\
\hline & Are you male or female? & Number of cases & Mean & SD & Mean of standard error \\
\hline \multirow{2}{*}{$\begin{array}{c}\text { All in all, I am satisfied } \\
\text { with my work }\end{array}$} & Female & 3596 & 3.15 & .605 & .010 \\
\cline { 2 - 6 } & Male & 2638 & 3.13 & .640 & .012 \\
\hline
\end{tabular}

Table 7 Independent sample T test of teacher gender and job satisfaction

\begin{tabular}{|c|c|c|c|c|c|c|c|c|c|c|}
\hline \multicolumn{11}{|c|}{ Independent sample test } \\
\hline & & \multicolumn{2}{|c|}{$\begin{array}{c}\text { Levine test of equal } \\
\text { variance }\end{array}$} & \multicolumn{7}{|c|}{ Mean equality $\mathrm{T}$ test } \\
\hline & & \multirow[b]{2}{*}{$\mathrm{F}$} & \multirow{2}{*}{ Significance } & \multirow{2}{*}{$\mathrm{t}$} & \multirow{2}{*}{ DOF } & \multirow{2}{*}{$\begin{array}{l}\text { Significance } \\
\text { (double tail) }\end{array}$} & \multirow{2}{*}{$\begin{array}{c}\text { Mean } \\
\text { difference }\end{array}$} & \multirow{2}{*}{$\begin{array}{l}\text { Standard error } \\
\text { difference }\end{array}$} & \multicolumn{2}{|c|}{$\begin{array}{l}\text { The difference } 95 \% \\
\text { confidence interval }\end{array}$} \\
\hline & & & & & & & & & $\begin{array}{c}\text { Inferior } \\
\text { limit }\end{array}$ & $\begin{array}{l}\text { Upper } \\
\text { limit }\end{array}$ \\
\hline \multirow{2}{*}{$\begin{array}{l}\text { All in all, I am } \\
\text { satisfied with my } \\
\text { work }\end{array}$} & $\begin{array}{c}\text { Assumed } \\
\text { equal variance }\end{array}$ & 1.378 & .240 & 1.241 & 6232 & .215 & .020 & .016 & -.011 & .051 \\
\hline & \begin{tabular}{|c|}
$\begin{array}{c}\text { Not assume } \\
\text { equal variance }\end{array}$ \\
\end{tabular} & & & 1.231 & 5495.327 & .219 & .020 & .016 & -.012 & .051 \\
\hline
\end{tabular}

Because the significance is greater than 0.05, the null hypothesis cannot be rejected. Therefore, there is no difference in job satisfaction between male and female teachers.

\subsection{The influence of teachers' academic qualifications on teachers' job satisfaction}

H0: There is no effect of teacher's degree on the job satisfaction of teachers, that is, there is no difference in the job satisfaction of all levels of education.

H1: At least two levels differ in job satisfaction.

Test method: single factor ANOVA test.

Table 8 Statistical table of teachers' highest degree description

\begin{tabular}{|c|c|c|c|c|c|c|c|c|}
\hline \multicolumn{9}{|c|}{ Description } \\
\hline \multicolumn{9}{|c|}{ All in all, I am satisfied with my work. } \\
\hline & \multirow{2}{*}{$\begin{array}{l}\text { Number of } \\
\text { cases }\end{array}$} & \multirow[t]{2}{*}{ Mean } & \multirow[t]{2}{*}{ SD } & \multirow{2}{*}{$\begin{array}{l}\text { Standard } \\
\text { error }\end{array}$} & \multicolumn{2}{|c|}{$\begin{array}{l}\text { 95\% confidence interval for the } \\
\text { average }\end{array}$} & \multirow[t]{2}{*}{ Minimum } & \multirow[t]{2}{*}{ Maximum } \\
\hline & & & & & Inferior limit & Upper limit & & \\
\hline Junior college and below & 618 & 3.13 & .577 & .023 & 3.09 & 3.18 & 1 & 4 \\
\hline Bachelor & 5143 & 3.14 & .624 & .009 & 3.13 & 3.16 & 1 & 4 \\
\hline Master and phd & 482 & 3.11 & .634 & .029 & 3.05 & 3.16 & 1 & 4 \\
\hline Total & 6243 & 3.14 & .620 & .008 & 3.12 & 3.15 & 1 & 4 \\
\hline
\end{tabular}


Table 9 Sample variance homogeneity test table

\begin{tabular}{|c|c|c|c|}
\hline \multicolumn{4}{|c|}{ Homogeneity test of variances } \\
\hline \multicolumn{4}{|c|}{ All in all, I am satisfied with my work } \\
\hline Levin statistics & DOF 1 & DOF 2 & Significance \\
\hline 4.568 & 2 & 6240 & .010 \\
\hline
\end{tabular}

Table 10 Variance analysis of teachers' highest educational background and job satisfaction

\begin{tabular}{|c|c|c|c|c|c|}
\hline \multicolumn{6}{|c|}{ ANOVA } \\
\hline \multicolumn{6}{|c|}{ All in all, I am satisfied with my work } \\
\hline & Quadratic sum & DOF & Mean square & $\mathrm{F}$ & Significance \\
\hline Among groups & .619 & 2 & .309 & .805 & .447 \\
\hline Intra groups & 2399.254 & 6240 & .384 & & \\
\hline Total & 2399.872 & 6242 & & & \\
\hline
\end{tabular}

Table 11 Post-test of variance analysis of teachers' highest educational background and job satisfaction

\begin{tabular}{|c|c|c|c|c|c|c|}
\hline \multicolumn{7}{|c|}{ Multiple comparison } \\
\hline \multicolumn{7}{|c|}{ Dependent Variable: All in all, I am satisfied with my work } \\
\hline \multicolumn{7}{|c|}{ LSD } \\
\hline \multirow{2}{*}{$\begin{array}{l}\text { (I) What is the highest degree } \\
\text { you have completed in formal } \\
\text { education? }\end{array}$} & \multirow{2}{*}{$\begin{array}{l}\text { J) What is the highest degree } \\
\text { you have completed in } \\
\text { formal education? }\end{array}$} & \multirow{2}{*}{$\begin{array}{c}\text { Mean } \\
\text { difference } \\
\text { (I-J) }\end{array}$} & \multirow{2}{*}{$\begin{array}{c}\text { Standard } \\
\text { error }\end{array}$} & \multirow[b]{2}{*}{ Significance } & \multicolumn{2}{|c|}{ 95\% confidence interval } \\
\hline & & & & & Inferior limit & Upper limit \\
\hline \multirow{2}{*}{ Junior college and below } & Bachelor & -.010 & .026 & .709 & -.06 & .04 \\
\hline & Master and phd & .027 & .038 & .476 & -.05 & .10 \\
\hline \multirow{2}{*}{ Bachelor } & Junior college and below & .010 & .026 & .709 & -.04 & .06 \\
\hline & Master and phd & .037 & .030 & .214 & -.02 & .09 \\
\hline \multirow{2}{*}{ Master and phd } & Junior college and below & -.027 & .038 & .476 & -.10 & .05 \\
\hline & Bachelor & -.037 & .030 & .214 & -.09 & .02 \\
\hline
\end{tabular}

Because the significance is greater than 0.05, the null hypothesis cannot be rejected. Therefore, teachers' academic qualifications have no effect on teachers' job satisfaction, that is, there is no difference in job satisfaction among all levels of academic qualifications.

In short, there was no statistically significant difference. In other words, gender and educational background have no significant influence on teachers' job satisfaction.

\section{Conclusion}

\subsection{The influence of gender on teacher satisfaction}

In conclusion, the option "I am satisfied with my work" is a little general.

In Xu Zhiyong's research, the measurement of teachers' job satisfaction mainly includes three basic levels: 1 . Intrinsic job satisfaction, which refers to the satisfaction brought by the job itself, such as development opportunity, stability, and sense of achievement; 2. Extrinsic job satisfaction, which refers to the work load, remuneration, welfare benefits, office conditions to bring the teachers' satisfaction; 3. Overall satisfaction refers to the integration of internal and external satisfaction, and refers to the overall and comprehensive emotional response of teachers to their work.

In terms of teacher gender variables, the intrinsic satisfaction of both male and female teachers reached a very high level (4.42 and 4.31, respectively), but there was no significant difference 
between them ( $p=0.06>0.05)$.However, in terms of external satisfaction and overall satisfaction, the satisfaction level of male teachers was significantly higher than that of female teachers $(\mathrm{p}<0$. 05).

However, this study only selects the overall satisfaction of teachers as a variable, which is rather general and cannot well prove that there is no difference between male and female teachers in their job satisfaction.

In addition, because question 8 is in the last of TC026, teachers have a sense of burnout when making choices of similar questions, resulting in more balanced answers from teachers. The relationship between gender and teacher job satisfaction cannot be well analyzed.

\subsection{The influence of educational background on teacher satisfaction}

In this study, the distribution of educational qualifications of the investigated teachers is unbalanced. Among them, teachers with a college degree or less account for $9.7 \%$, those with a master's degree or doctor's degree account for 7.5\%, and those with a bachelor's degree account for 82.3\%.As a result, the data cannot well prove the influence of academic degree on teacher satisfaction.

In addition, the job satisfaction of teachers is actually affected by such factors as the teacher's title, age, specific job position, teacher-student relationship, school cultural atmosphere, and school type (public/private, urban/rural). However, these factors were not excluded in the statistical analysis, so gender and educational background had no significant impact on teachers' job satisfaction.

\section{Acknowledgements}

The authors gratefully acknowledge professor support from.

\section{References}

[1] Chen chun-geun. Empirical research on influencing factors of middle school teachers' job satisfaction -- an analysis based on PISA2015 teacher survey data [J]. Teacher education research, 2017, 29 (2): 84-91.

[2] Chen yunying, sun shaobang. Measurement of teacher job satisfaction [J]. Psychological science, 1993,17 (03): 146-149.

[3] Feng baolin. Research on teacher job satisfaction and its influencing factors [J]. Education research, 1996 (02): $42-49+6$.

[4] Gong huoliang. Research on the status quo of job satisfaction of high school teachers in henan province [D]. Henan: henan university, 2002.

[5 ]Huang cuixia, xing yiqun. Measurement and analysis of employee satisfaction [J]. Enterprise vitality, 2002 (02): 50-51.

[6] Hu yongmei. An empirical study on job satisfaction of middle school teachers and its influencing factors [J]. Journal of education, 2007, 3 (5): 46-52.

[7] Kong lihua. Research on the relationship among employee personality traits, job satisfaction and turnover intention [D]. Shanghai: east China normal university, 2006.

[8] Kong weimin. Study on organizational atmosphere, achievement motivation and job satisfaction in schools [D]. Beijing: Beijing normal university, 2003.

[9] Locke, E. What is job satisfaction? [J]. Organizational Behavior and Human Performance, 1969, 4 (4): $309-336$.

[10] Porter, L.W.\& Steer, R. M. Organizational work and personal factors in employee turn-over and absenteeism [J]. Psychological Bulletin, 1973, 80 (2): 151-176.

[11] Roberts, K. H. ,Walter, G.A., \&Miles, R.E.A Factor analytic study of job satisfaction items designed to measure Maslow need categories [J]. Personnel Psychology, 1971, 24: 205-220.

[12] Spector, P.E, Job Satisfaction: Application, Assessment, Causes, and Consequences. [M]. Thousand Oaks: Sage Publications, 1997.

[13] Vroom, V.H.Work and Motivation. [J] San Francisco, CA: Jossey-Bass. 1964. 
[14] Xu Zhiyong \& Zhao Zhihong. Empirical study on job satisfaction of primary school teachers in Beijing [J]. Teacher education research, 2012, 24 (1) : 85-92. 